\title{
Weed Competition in a Mature Matted Row Strawberry Planting
}

\author{
Marvin P. Pritts and Mary Jo Kelly \\ Department of Horticulture, Cornell University, Ithaca, NY 14853
}

\begin{abstract}
Additional index words. cultivation, Fragaria $\times$ ananassa, integrated weed management, thresholds
\end{abstract}

\begin{abstract}
Various levels of weed competition were implemented in a second-year well-established strawberry (Fragaria $\times$ ananassa 'Jewel') planting by cultivating and hand weed removal for defined periods of time over 3 years. The impact of weeds on subsequent productivity was then determined. Sixteen treatments were established where weeds were allowed to grow for defined periods $(0,1,2,3,4$, or 5 months) throughout the growing season. Treatments were maintained in the plots for 3 consecutive years. Spring weed biomass in 1997 had no impact on yield that same year. Weed biomass in 1997 was negatively associated with yield in 1998, although the trend was nonsignificant. However, several individual contrasts were significant. For example, the weed-free control treatment had the highest average yield, while season-long weed competition reduced yield by $14 \%$. The inverse relationship between weed biomass and fruit yield became significant in 1999. For every $100 \mathrm{~g} \cdot \mathrm{m}^{-2}$ increase in weed biomass in 1998, fruit yield was reduced by $6 \%$ in 1999. Season-long uncontrolled weed growth reduced productivity by $51 \%$. However, several plots with a limited amount of weed competition had higher yields than the continuously weeded control. These data indicate that yields from a well-established strawberry planting may not be vulnerable to a limited amount of weed competition for at least 2 years. Furthermore, data suggest that hand weeding and cultivation on a monthly basis for multiple years may be damaging as well. Growers should direct a majority of their efforts and resources toward controlling weeds in the planting year. Once the planting is well-established, growers may limit the number of times they hand weed to two or three per season.
\end{abstract}

Implementation of IPM for weeds requires that herbicide applications or mechanical cultivation be based on damage thresholds rather than calendar date or the mere presence of weeds in a field. A few studies have examined weed competition in perennial fruit crops such as apples, tart cherries, and raspberries, and all suggest that weed competition early in the growing season is more detrimental than late season competition (Al-Hinai and Roper, 2001; Lawson and Wiseman, 1976a; Merwin and Ray, 1997). Knowing when weed growth is most detrimental to crop performance allows managers to use their resources more efficiently. Such knowledge would be particularly important for perennial strawberry growers where herbicide options are very limited, and weed management is labor intensive.

Lawson and Wiseman (1976b) attempted to identify times during the planting year when perennial strawberries are most vulnerable to weed competition. When weeding was delayed for 2 months or longer, runner development was inhibited, plant mortality increased, plant size was reduced, and yields were suppressed. Yield differences were attributed mostly to the number of inflorescences per plant. When the experiment was repeated the following year, several of the weedy treatments had significantly more inflorescences than the weed-free control.

Received for publication 31 Jan. 2003. Accepted for publication 21 May 2003. This work was partially funded by the North American Strawberry Growers Association and Hatch project NYC-145400. The authors thank Ian Merwin and Robin Bellinder for helpful reviews of the manuscript.
Differences between the 2 years were attributed to seasonal rainfall patterns. The authors suggested that within-plant competition from uncontrolled runner growth can inhibit branch crown formation and subsequent inflorescence production as much as limited weed competition in plots kept weed-free. They even suggested that limited weed competition might enhance productivity by restricting runner development during seasons when plants are environmentally stressed and competition between runner growth and crown and truss production is great. In both years of this study, weed competition late in the season had little effect on runnering or productivity.

Vézina and Bouchard (1989) reported that weeds in a new strawberry planting reduced yield by as much as $50 \%$ in the first fruiting year, and attributed this reduction to inhibited rooting of daughter plants and delayed development of mother plants. Pritts and Kelly (2001) examined the effects of weed competition at different times and for varying lengths of time on growth and productivity of newly planted strawberries. They also reported that spring weed growth was detrimental to productivity and that lateseason competition had little impact on yield. Their data also showed an inverse relationship between the length of the competitive period, and runnering and yield.

The studies reported here were initiated in the planting year and ended upon fruiting the following year. To our knowledge, there are no reports on the effects of timing and duration of weed competition in plantings older than 1 year. Differences between new and established plantings can be expected because mature plantings often have greater perennial weed populations, and differences exist in the techniques used to manage weeds. For example, more herbicides are labeled for use in bearing fields than in non-bearing fields, and cultivation rather than mulch is used for weed control in the planting year. Information on the magnitude and effect of weed competition on productivity in mature plantings could be extremely useful for making management decisions, particularly regarding the use of labor for hand weeding and cultivation operations.

The goals of this study were to 1) identify times during the growing season when a mature strawberry planting is most susceptible to competition from weeds, 2) determine the length of time weeds must be present to negatively impact crop performance, and 3) determine if the influence of these factors changes with the age of planting.

\section{Materials and Methods}

The site for this study was previously planted in apple trees and located at the Cornell Orchards in Ithaca, N.Y. The soil is predominantly a silty clay loam of the Hudson series (Typic Hapludalf). The area was cleared of trees in 1994, treated with glyphosate herbicide $\left(2.3 \mathrm{~kg} \cdot \mathrm{ha}^{-1}\right.$ a.i.) in April 1995, and seeded in rye (Secale cereale L.) in September 1995. The rye was incorporated the following spring, and 1 week later the site was tilled a second time. 'Jewel' strawberry plants (Sanford, 1985) were set on 29 May 1996, spaced 0.5-m in-row and 1.25$\mathrm{m}$ between-rows, and grown in the matted row system. The planting was divided into 64 plots consisting of three 3-m-long adjacent rows. The two outer rows served as border rows and data were collected from the middle row only.

All plots were managed the same in the planting year. A healthy stand was established, and herbicides were used to supplement hand weeding, hoeing, and cultivation to maintain a weed-free planting through early October. Napropamide (Devrinol, $2.3 \mathrm{~kg} \cdot \mathrm{ha}^{-1}$ a.i.) was applied 2 weeks after planting and DCPA (Dacthal, $8.5 \mathrm{~kg} \cdot \mathrm{ha}^{-1}$ a.i.) was applied in late July. Napropamide (Devrinol, $4.6 \mathrm{~kg} \cdot \mathrm{ha}^{-1}$ a.i.) was applied a second time in late November, and the planting was weed-free at the onset of winter. A thick layer $\left(7.0 \mathrm{t} \cdot \mathrm{ha}^{-1}\right)$ of wheat (Triticum aestivum) straw mulch was broadcast over the planting in late November for each of the 3 years, and in mid-March the straw was raked off the crop rows and into the alleyways. No herbicides were used in subsequent years.

Sixteen treatments were imposed on the planting in 1997-99 (Table 1). Native weeds were allowed to grow for a 1-month period (May, June, July, August, or September), a 2-month period (May-June, June-July, July-August, or August-September), a 3-month period (May-July, June-August, or July-September), or a 4-month period (May-August or June-September). Two additional treatments also were included-one in which weeds were permitted to grow throughout the season (May-September), and one which served as a weed-free control. Treatments were replicated four times in a randomized complete-block 
Table 1. Effects of varying periods of weed ${ }^{z}$ competition (W) and suppression (---) in 1997 and 1998 on weed biomass, sampled after each continuous weed growth period.

\begin{tabular}{|c|c|c|c|c|c|c|c|c|c|c|c|c|}
\hline \multirow[b]{3}{*}{ May } & \multirow[b]{3}{*}{ June } & \multirow{2}{*}{\multicolumn{2}{|c|}{ Treatment }} & \multirow[b]{3}{*}{ Sept } & \multicolumn{8}{|c|}{ Weed fresh wt $\left(\mathrm{g} \cdot \mathrm{m}^{-2}\right)$} \\
\hline & & & & & \multicolumn{4}{|c|}{1997} & \multicolumn{4}{|c|}{1998} \\
\hline & & July & Aug & & $\mathrm{ABL}$ & PBL & Grasses & Total & ABL & PBL & Grasses & Total \\
\hline--- & --- & --- & --- & --- & 1 & 5 & 1 & 7 & 0 & 0 & 0 & 0 \\
\hline W & --- & --- & --- & --- & 1 & 43 & 1 & 45 & 25 & 17 & 1 & 43 \\
\hline --- & W & --- & --- & --- & 6 & 149 & 1 & 156 & 9 & 28 & 0 & 37 \\
\hline --- & --- & W & --- & --- & $\mathrm{NA}^{\mathrm{y}}$ & NA & NA & 102 & 7 & 13 & 0 & 20 \\
\hline--- & --- & --- & W & --- & 1 & 23 & 1 & 25 & 24 & 101 & 38 & 163 \\
\hline --- & --- & --- & --- & W & 67 & 26 & 0 & 93 & 1 & 3 & 0 & 4 \\
\hline W & W & --- & --- & --- & 6 & 76 & 2 & 84 & 17 & 92 & 9 & 118 \\
\hline --- & W & W & --- & --- & NA & NA & NA & 230 & 6 & 22 & 10 & 38 \\
\hline --- & --- & W & W & --- & 4 & 74 & 0 & 78 & 59 & 112 & 34 & 205 \\
\hline--- & --- & --- & W & W & 65 & 74 & 0 & 139 & 167 & 118 & 8 & 293 \\
\hline W & W & W & --- & --- & NA & NA & NA & 110 & 18 & 59 & 0 & 77 \\
\hline --- & W & W & W & --- & 0 & 78 & 0 & 78 & 60 & 227 & 26 & 313 \\
\hline --- & --- & W & W & W & 20 & 75 & 28 & 123 & 160 & 119 & 23 & 302 \\
\hline W & W & W & W & --- & 0 & 102 & 0 & 102 & 5 & 520 & 22 & 547 \\
\hline --- & W & W & W & W & 8 & 299 & 12 & 319 & 11 & 444 & 34 & 489 \\
\hline $\mathrm{W}$ & W & W & W & W & 8 & 229 & 4 & 241 & 52 & 480 & 9 & 541 \\
\hline $\operatorname{LSD}_{(0.05)}$ & & & & & 53 & 123 & 23 & 147 & 97 & 209 & 35 & 235 \\
\hline
\end{tabular}

${ }^{\mathrm{z}}$ Annual (ABL) and perennial (PBL) broadleaf weeds.

${ }^{\mathrm{y}} \mathrm{NA}=$ data for individual weed categories not available for July 1997 weed harvest.

design and were continued within the same planting for 3 consecutive years on the same plots, until the experiment was terminated after harvest in the third year. Plots were kept weed-free at the appropriate times by hand weeding, hoeing, and cultivation. Insect pests and diseases were managed following commercial guidelines (Pritts et al., 1996). Standard cultural practices were employed throughout the study (Pritts and Handley, 1998), including overhead irrigation and renovation after harvest. Renovation included mowing the leaves at crown height within 2 weeks after the last harvest, narrowing rows to $20 \mathrm{~cm}$ using a multivator, and fertilizing with $80 \mathrm{~kg} \cdot \mathrm{ha}^{-1} \mathrm{~N}$ in the form of ammonium nitrate.

Weed biomass was assessed in 1997 and 1998. Weeds were harvested from the appropriate plots at the end of each weedy period by cutting at ground level from a 1.25 -m-wide $\times 3$-m-long area centered over the data row, sorted by species, and weighed. Fruit yield data were collected in 1997, 1998, and 1999. In 1997, yield data were collected from only the four treatments which were implemented prior to June harvest. Plots were harvested every 2 to $3 \mathrm{~d}$ from 27 June to 10 July 1997, 9 to 29 June 1998, and 16 June to 7 July 1999. Average berry size was determined from at least a 600 -g subsample of marketable fruit randomly selected at each harvest. Fruit were counted and weighed, and individual seasonal berry weight was determined. The field was renovated on 4 Aug. 1997 and 17 July 1998.

Analysis of variance was used to test the significance of differences among treatment means (SuperANOVA, Abacus Concepts, Berkeley, Calif.), and regression analysis was employed to examine the relationship between accumulated weed biomass and yield (Microsoft Excel, Microsoft Corp., Redmond, Wash.).

\section{Results and Discussion}

Weed biomass was greatest in those treatments where weeds were allowed to establish early and grow for an extended period of time (Table 1). Perennial broadleaf weeds became established in the planting as early as June of the second year after planting and were responsible for most of the treatment differences in accumulated biomass. Yellow toadflax (Linaria vulgaris Mill.), yellow woodsorrel (Oxalis stricta L.), dandelion (Taraxacum officinale Weber) and several dock species (Rumex sp.) comprised this fraction of weed biomass. Annual broadleaf weeds became established in the planting later in the season, and usually represented a smaller fraction of total weed biomass. This fraction consisted of common groundsel(Senecio vulgaris L.), yellow rocket (Barbarea vulgaris R. Br.), ladysthumb (Polygonum persicaria $\mathrm{L}$.) and several pigweed species (Amaranthus sp.). Grass (Gramineae) species [mostly quackgrass, Elytrigia repens (L.) Nevski; and yellow foxtail, Setaria glauca (L). (Beauv.)] contributed little to total weed biomass in 1997 and 1998. In general, weed biomass was greater in 1998 than in 1997, suggesting a cumulative increase in weed competition over time.

Strawberry productivity was not affected by any amount of weed growth in the first year (Fig. 1, Table 2), and only certain contrasts were significant in the second year (1998). For example, in 1998, the weed-free control plots had the highest average yield, and season-long competition reduced yield by $14 \%$. An inverse relationship between weed biomass and yield became more pronounced and significant in 1999 (Fig. 1, Table 2). Seasonlong uncontrolled weed growth reduced productivity by $51 \%$ in comparison to the weed-free control.
However, several treatments with a small amount of weed competition had even higher yields than the continuously weeded control, suggesting that intensive hand weeding and cultivation on a regular basis for an extended period of time may be damaging as well. Lawson and Wiseman (1976b) speculated that uncontrolled runner growth in weed-free plots can inhibit branch crown development and inflorescence production and, hence, reduce yield. We speculate that, in our study, the slightly lower yields of the weed-free plots compared to certain weedy plots in the third year were due to repeated disturbance of the strawberry root system when both above and below ground weed biomass were removed during weeding.

Yield and fruit size of all treatments declined in our study from 1998 to 1999, and it is unclear if these declines were due to weather factors, to increasing competition among straw-

Fig. 1. Regression of fruit yield of an established planting of 'Jewel' strawberry on current season $\left(1997, \mathrm{y}=0.488 \mathrm{x}+2894, R^{2}=0.01\right)$ and previous season $\left(1998, \mathrm{y}=-0.274 \mathrm{x}+4060, R^{2}=0.01\right.$; and $\left.1999, \mathrm{y}=-1.616 \mathrm{x}+2700, R^{2}=0.40, P<0.01\right)$ weed biomass. To convert yield from $\mathrm{g} \cdot \mathrm{m}^{-1}$ to $\mathrm{g} \cdot \mathrm{m}^{-2}$, multiply by 0.33 .

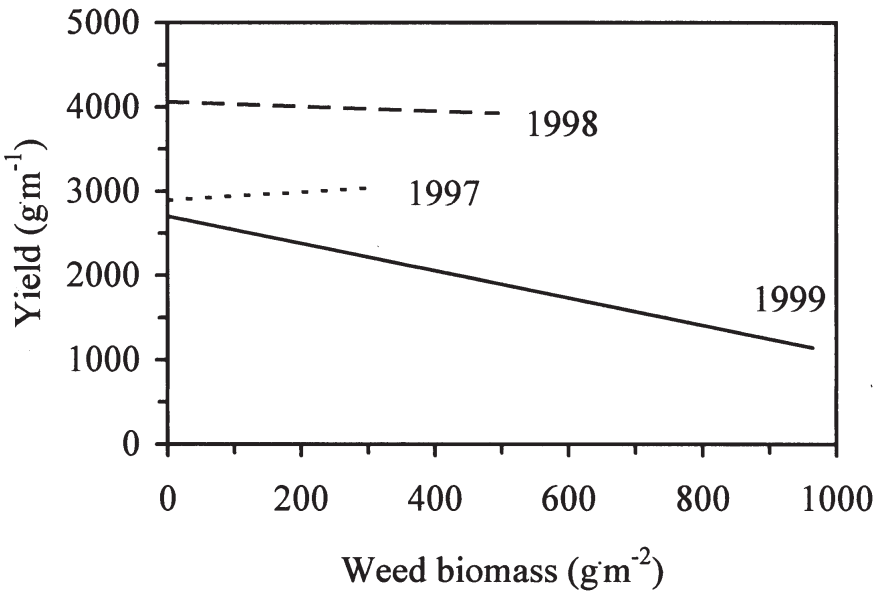


Table 2. Effects of varying periods of weed competition (W) and suppression (---) in 1997 and 1998 on current and subsequent year's yield and fruit size of 'Jewel' strawberry.

\begin{tabular}{|c|c|c|c|c|c|c|c|c|c|c|}
\hline \multicolumn{5}{|c|}{ Treatment } & \multicolumn{3}{|c|}{ Yield $\left(\mathrm{g} \cdot \mathrm{m}^{-1}\right)$} & \multicolumn{3}{|c|}{ Berry wt (g) } \\
\hline May & June & July & Aug. & Sept. & 1997 & 1998 & 1999 & 1997 & 1998 & 1999 \\
\hline--- & --- & --- & ---- & --- & 2907 & 4462 & 2340 & 14.8 & 15.8 & 9.2 \\
\hline W & --- & --- & --- & --- & 2911 & 4269 & 2944 & 12.0 & 15.0 & 10.1 \\
\hline --- & W & --- & --- & --- & 2933 & 3884 & 2317 & 12.8 & 15.6 & 9.1 \\
\hline --- & --- & W & --- & --- & --- & 4043 & 2848 & --- & 15.2 & 9.3 \\
\hline --- & --- & --- & W & --- & --- & 3811 & 2566 & --- & 14.7 & 8.1 \\
\hline --- & --- & --- & --- & W & --- & 4167 & 2836 & --- & 15.8 & 9.7 \\
\hline W & W & --- & --- & --- & 2967 & 3832 & 2397 & 13.5 & 15.2 & 9.5 \\
\hline --- & W & W & --- & --- & --- & 4242 & 3002 & --- & 16.3 & 10.0 \\
\hline --- & --- & W & W & --- & --- & 3814 & 2368 & --- & 16.2 & 9.3 \\
\hline --- & --- & --- & W & W & --- & 4092 & 2494 & --- & 15.7 & 9.1 \\
\hline W & W & W & --- & --- & --- & 4090 & 2747 & --- & 16.7 & 8.6 \\
\hline --- & W & W & W & --- & --- & 3987 & 2225 & --- & 16.6 & 9.1 \\
\hline --- & --- & W & W & W & --- & 3890 & 2294 & --- & 15.3 & 8.8 \\
\hline W & W & W & W & --- & --- & 3780 & 2310 & --- & 15.9 & 9.4 \\
\hline --- & W & W & W & W & --- & 4240 & 1224 & --- & 15.3 & 9.1 \\
\hline W & W & W & W & W & --- & 3820 & 1153 & --- & 15.2 & 8.8 \\
\hline $\operatorname{LSD}_{(0.05}$ & & & & & 733 & 571 & 596 & 2.4 & 1.2 & 1.4 \\
\hline
\end{tabular}

berry crowns, or to the cumulative effects of weed-crop competition over time. May-June rainfall was $21 \mathrm{~cm}$ in 1998 , but only $7 \mathrm{~cm}$ in 1999, although we compensated for the reduced rainfall with irrigation. The decline in productivity also could have been due to increasing competition among crowns within the planting (Swartz et al. 1982). In our study, berry weight declined in the third year, but we are unsure if this is a reflection of intraplant competition, because we did not collect data on crown density.

Previous studies (Lawson and Wiseman, 1976b; Pritts and Kelly, 2001) have documented the importance of timing of weed suppression in the planting year. We found weed suppression timing to be of no importance in established plantings within a given year. Measuring the impact of weed competition duration is difficult in established plantings because the commercial practice of renovation temporarily, but significantly, reduces weed biomass. In our study, effects of weeds on yield were not detected until weeds had accumulated for at least 2 years. Although the presence of weeds in earlier years may not have affected yield, it could have affected harvest efficiency and pest pressure. We did not quantify these effects.

The cumulative effects of weed competition over time are obvious (Fig. 1). For every $100 \mathrm{~g} \cdot \mathrm{m}^{-2}$ increase in weed biomass, yield was unaffected in 1997, reduced by less than $1 \%$ in 1998, and reduced by $6 \%$ in 1999. Data also indicate that a well-established strawberry planting may not be vulnerable to a limited amount of weed competition for at least 2 years. Therefore, growers should direct most of their efforts and resources toward controlling weeds in the planting year, where weed competition is known to have deleterious effects (Lawson and Wiseman, 1976b; Pritts and Kelly, 2001). Clearly, season-long competition is detrimental to crop growth and productivity, but hand weeding and cultivation on a monthly basis for multiple years may be damaging as well
(Hill and Alban, 1963). Once the planting is well established, growers may want to limit the number of times they hand weed and cultivate to 2 or 3 times per season, and supplement this with well-timed herbicide applications to reduce potential damage to soil structure and strawberry root systems.

\section{Literature Cited}

Al-Hinai, Y.K. and T.R. Roper. 2001. Temporal effects of chemical weed control on tart cherry tree growth, yield, and leaf nitrogen concentration. HortScience 36:80-82.

Hill, R.G. and E.K. Alban. 1963. Strawberry stands and yields as related to weed control methods. Proc. Amer. Soc. Hort. Sci. 82:292-298.

Lawson, H.M. and J.S. Wiseman. 1976a. Weed competition in spring-planted raspberries. Weed Res. 16:155-162.

Lawson, H.M. and J.S. Wiseman. 1976b. Weed competition in spring-planted strawberries. Weed Res. 16:345-354.

Merwin, I.A. and J.A. Ray. 1997. Spatial and temporal factors in weed interference with newly planted apple trees. HortScience 32:633-637.

Pritts, M., A. Agnello, G. English-Loeb, and W. Wilcox. 1996. Pest management recommendations for small fruit crops. Cornell Univ., Ithaca, N.Y.

Pritts, M. and D. Handley. 1998. Strawberry production guide for the Northeast, Midwest and eastern Canada. Northeast Reg. Agr. Eng. Serv. 88 , Ithaca, N.Y.

Pritts, M. and M.J. Kelly. 2001. Early season weed competition reduces yield of newly planted matted row strawberries. HortScience 36:729-731.

Sanford, J.C. 1985. 'Jewel' strawberry. HortScience 20:1136-1137.

Swartz, H.J., C.S. Walsh, A.F. Geyer, L. Douglass, G.J. Galetta, and R.H. Zimmerman. 1982. Plant crown competition in strawberry matted rows. Adv. Strawberry Prod. 1:6-11.

Vézina, L. and C.J. Bouchard. 1989. Compétition de la petite oseille (Rumex acetosella L.) avec le fraisier cultivé (Fragaria ananassa Dcne). Naturaliste Can. 116:237-243. (Abstr.) 